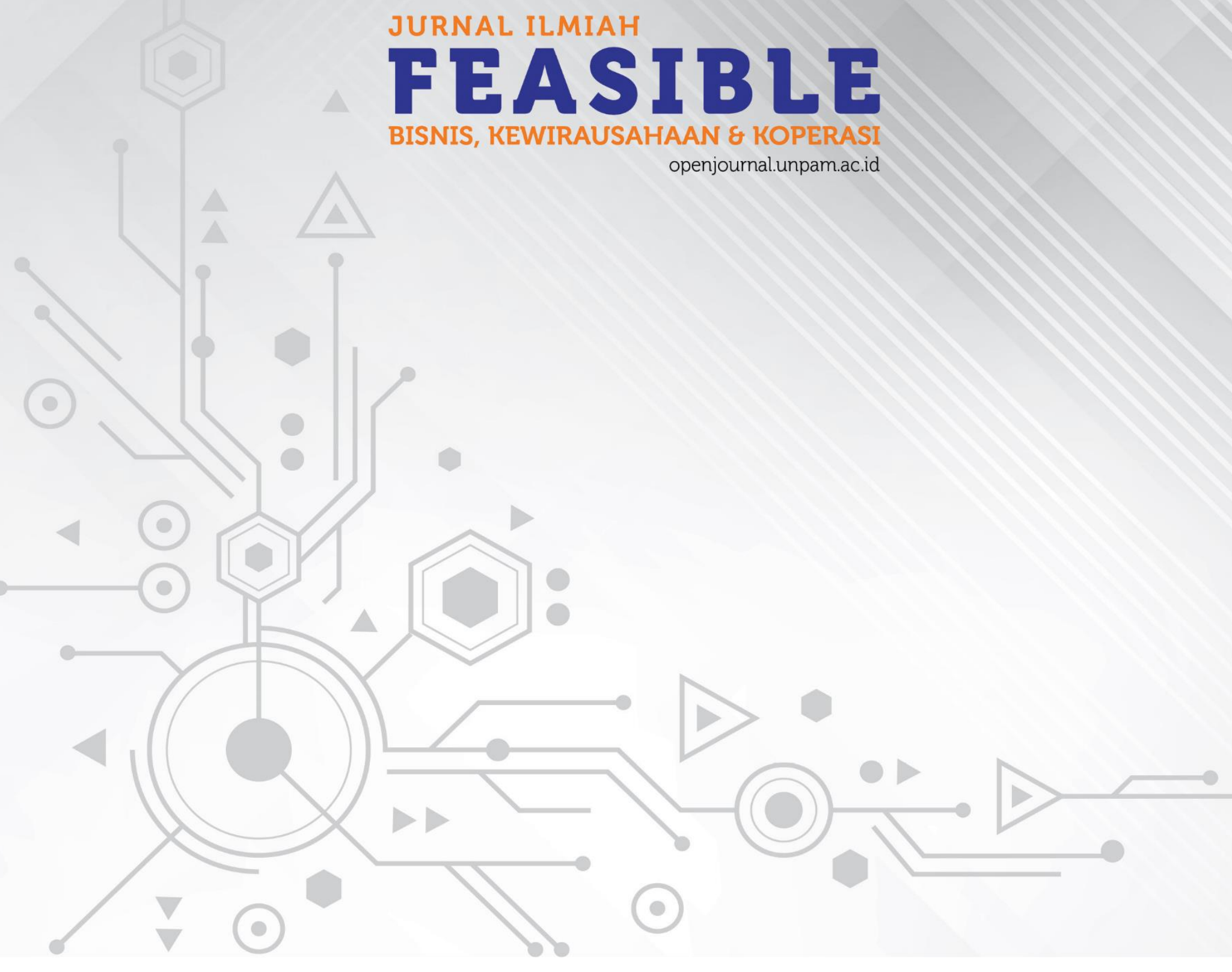




\title{
PENGARUH BUDAYA ORGANISASI DAN DISIPLIN KERJA TERHADAP PRODUKTIVITAS KERJA KARYAWAN PADA KOPERASI SIMPAN PINJAM SEJAHTERA BERSAMA BOGOR
}

\author{
Jeni Andriani , Sigit Purnomo \\ Fakultas Ekonomi, Universitas Pamulang \\ jeni.andriani@yahoo.co.id, sigit82purnomo@gmail.com
}

\begin{abstract}
Abstrak
Penelitian ini bertujuan untuk mengetahui pengaruh budaya organisasi dan disiplin kerja terhadap produktivitas kerja karyawan pada Koperasi Simpan Pinjam Sejahtera Bogor. Metode penelitian yang digunakan yaitu deskriptif kualitatif dengan pengujian validitas, reliabilitas, asumsi klasik, regresi linier berganda, uji determinasi, uji t dan uji F. Sampel yang digunakan sebanyak 60 responden dari populasi 150 orang dengan menggunakan rumus slovin. Hasil penelitian diperoleh bahwa budaya organisasi secara parsial berpengaruh terhadap produktivitas karyawan. Demikian pula disiplin kerja karyawan juga berpengaruh secra parsial. Pengujian regresi ganda diperoleh persamaan regresi $\hat{Y}=$ $52,381+0,048 \mathrm{X}_{1}+1,000 X_{2}$. Hasil uji $F$ diperoleh nilai $F_{\text {hitung }}=8098,471$ lebih besar dari $F_{\text {tabel }}$ 3,16o sehingga secara simultan atau bersama-sama terdapat pengaruh yang positif dan signifikan antara budaya organisasi dan disiplin kerja terhadap produktivitas karyawan dengan konstribusi 99,6\%.
\end{abstract}

Kata Kunci: Budaya Organisasi, Disiplin Kerja dan Produktivitas

\begin{abstract}
This study aims to determine the effect of organizational culture and work discipline on employee work productivity at the Prosperous Savings and Credit Cooperative in Bogor. The research method used is descriptive qualitative by testing the validity, reliability, classic assumptions, multiple linear regression, determination test, $t$ test and $F$ test. The sample used was 60 respondents from a population of 150 people using the Slovin formula. The results showed that organizational culture partially influences employee productivity. Likewise, employee work discipline also has a partial effect. Multiple regression testing obtained a regression equation $\hat{Y}=52,381+0.048 X 1+1,000 X 2 . F$ test results obtained Fcount value $=$ 8098,471 is greater than Ftable 3,160 so that simultaneously or together there is a positive and significant effect between organizational culture and work discipline on employee productivity with a contribution of $99.6 \%$.
\end{abstract}

Keywords: Organizational Culture, Work Discipline and Productivity 


\section{PENDAHULUAN}

\section{Latar Belakang}

Dalam dunia pekerjaan dewasa ini kebutuhan akan sumber daya manusia yang berkompeten sangatlah tinggi hal ini dipengaruhi oleh persaingan dunia usaha yang semakin meningkat sehingga berpengaruh pula terhadap peningkatan produktivitas kerja karyawan. Karenanya dalam perencanaan, pengorganisasian, pelaksanaan pengendalian proses dalam manajemen sumber daya manusia sangatlah diperluan baik dalam fungsi atau bidang produksi, pemasaran, keuangan, maupun kepegawaian dalam setiap organisasi perusahaan.

Dengan demikian ketersedian SDM yang berkualitas diyakini sebagai kunci sukses yang utama dalam keberhasilan suatu organisasi atau perusahaan. Hal demikian membuat sumber daya manusia yang ada pada sebuah organisasi atau perusahaan berperan aktif dalam menjalankan strategi organisasinya demi tercapainya visi dan misi organisasi yang sudah dibuat pada awal terbentuknya organisasi tersebut. Dengan demikian perusahaan wajib menginvestasi SDM yang ada dan SDM yang akan datang agar dapat terus bekerja secara kompeten sehingga sasaran organisasi dapat tercapai secara efektif dan efisien.

Masalah utama dalam pengelolaan sumber daya manusia dihadapi oleh berbagai oraganisasi adalah tidak adanya perencanaan yang matang, prosedur yang terstruktur rapi dan sistematis dalam menjalankan fungsi dan aktivitas-aktivitas pengelolaan sumber daya manusianya. Akan tetapi budaya organisasi yang terterap dalam masing-masing organiasi itu sendiri. Seperti struktur organisasi yang harus terencana secara sistematis, upaya pengelolaan sumber daya manusia sering salah dalam menerapkan kompetensi dengan jenis atau unit pekerjaannya. Standar kerja yang baik dan terpola yang harus dimiliki oleh setiap organisasi hal ini dimungkinkan agar seluruh karwayan dapat bekerja dengan role yang sudah dibuat oleh organisasi yakni SOP (Standar Operasional Perusahaan). Menghilangkan budaya senioritas dalam perusahaan dengan budaya kompetisi yang baik, sehingga akan terkadi iklim persaingan berdasarkan prestasi kerja bukan lagi lama bekerja.

Berbicara tujuan dalam organisasi perusahaan yang lainnya adalah menyinggung mengenai kedisiplinan berkerja seluruh unit yang ada dalam organisasi tersebut, dimana masing-masing unit bekerja berdasarkan porsi yang sudah dirancang oleh organisasi agar sasaran utama yakni produktivitas kerja karyawan dapat tercapai secara efektif dan efisien. Setiap organisasi sudah memiliki standar kerja termasuk aturan mengenai kedisiplinan karyawan hal ini diciptakan agar dapat meningkatkan produktivitas kerja karyawannya agar dapat bekerja dengan optimal pada setiap unit kerjanya. 
Hal demikian bukan lagi mengenai punishment (peringatan) dan reward (penghargaan) melainkan kesadaran dari masing-masing pribadi karyawan itu sendiri. Berikut ini tingkat kedisiplinan karyawan pada Koperasi Simpan Pinjam Sejahtera Bersama Bogor tahun bulan JuniNovember 2018.

Tabel 1.1 Absen Karyawan Tahun 2018

\begin{tabular}{|l|c|c|c|c|cc|}
\hline \multirow{2}{*}{ Bulan } & Hari & Jumlah & \multicolumn{2}{c|}{ Absen } & Jumlah & Persentase \\
& Kerja & Karyawan & Izin & Sakit & $\begin{array}{c}\text { Absen } \\
\text { (\%) }\end{array}$ \\
\hline Juni & 20 & 60 & 8 & 4 & 12 & 20 \\
\hline Juli & 20 & 60 & 11 & 5 & 16 & 26,6 \\
\hline Agustus & 20 & 60 & 10 & 4 & 14 & 23,3 \\
\hline September & 20 & 60 & 5 & 2 & 7 & 11,6 \\
\hline November & 20 & 60 & 4 & 3 & 7 & 11,6 \\
\hline Desember & 20 & 60 & 5 & 3 & 8 & 13,3 \\
\hline
\end{tabular}

Dari tabel kehadiran diatas dari 150 orang karyawan dengan menggunakan sampel slovin sehingga ada 60 sampel responden terlihat jumlah karyawan setiap bulannya selalu ada yang absen dengan berbagai kondisi sehingga kedisiplinan karyawan akan berdampak pada pencapaian akhir perusahaan. Sehingga diperlukan aturan yang dapat memperbaiki tingkat disiplin kerja karyawan pada aspek kehadiran agar dapat berjalan dengan baik.

Sehubungan dengan produktivitas kerja merupakan tujuan yang ingin dicapai setiap organisasi perusahaan maka perusahaan menginginkan ouput yang besar agar keberlangsungan organisasi terus terjaga. Produktivitas kerja dapat terwujud apabila karyawan mampu menyelesaikan pekerjaan dan tugas-tugas yang diberikan oleh perusahaan.
Dari hasil penelitian kelokasi Koperasi Simpan Pinjam Sejahtera Bersama Bogor, penulis melihat bahwa produktivitas karyawan koperasi tersebut masih perlu ditingkatkan kembali, hal ini diartikan capaian produktivitas karyawan Koperasi Simpan Pinjam Sejahtera Bersama belum maksimal, seperti yang terlampir dalam tabel berikut.

Tabel 1.2. Hasil Produktivitas Koperasi Simpan Pinjam Sejahtera Bersama Bogor

\begin{tabular}{|c|c|c|c|c|}
\multirow{2}{*}{ Thn } & \multicolumn{2}{|c|}{ Pertumbuhan Dana Koperasi } & \multirow{2}{*}{ Ket. } \\
\cline { 2 - 4 } & Target & Hasil & (\%) & \\
\hline 2016 & 12.000 .000 .000 & 3.000 .000 .000 & 25 & $\begin{array}{c}\text { Belum } \\
\text { tercapai }\end{array}$ \\
\hline 2017 & 13.000 .000 .000 & 4.000 .000 .000 & 30,7 & $\begin{array}{c}\text { Belum } \\
\text { tercapai }\end{array}$ \\
\hline 2018 & 15.000 .000 .000 & 10.000 .000 .000 & 66,6 & $\begin{array}{c}\text { Belum } \\
\text { tercapai }\end{array}$ \\
\hline
\end{tabular}

Dari tabel 1.2 di atas tampak bahwa produktivitas karyawan Koperasi Simpan Pinjam Sejahtera Bersama menunjukan peningkatan setiap tahunnya akan tetapi capaian target perhatunnya selama 3 (tiga) tahun tidak ada yang tercapai. Rendahnya produktivitas terhadap capaian perusahaan dikarenakan masih rendahnya disiplin kerja serta budaya organisasi perusahaan yang belum sesuai standar kerja bagi karyawannya.

Berdasarkan permasalahan di atas, penelitian ini bertujuan untuk mengetahui:

1. Pengaruh budaya organisasi terhadap produktivitas kerja karyawan Koperasi Simpan Pinjam Sejahtera Bersama Bogor.

2. Pengaruh disiplin kerja terhadap produktivitas kerja karyawan Koperasi Simpan Pinjam Sejahtera Bersama Bogor. 
3. Pengaruh budaya organisasi dan disiplin kerja terhadap produktivitas kerja karyawan pada Koperasi Simpan Pinjam Sejahtera Bersama Bogor.

\section{Kajian Literatur}

\section{Budaya Organisasi}

Menurut Robbins (2014: 289), mengartikan "budaya organisasi adalah suatu persepsi bersama yang dianut oleh anggota-anggota organisasi tersebut. Sedangkan menurut Rahaman dalam bukunya Corporate Culture and Productivity" : Case Studies in Asia and The Pacific (2014) bahwa pengertian budaya organisasi kuat adalah sebuah budaya organisasi yang kuat akan terbentuk disaat sebuah organisasi mengalami tantangan dari luar organisasi

\section{Disiplin}

Kedisiplinan merupakan fungsi operasional manajemen sumber daya manusia yang terpenting dikarenakan semakin baik disiplin kerja karyawan, maka semakin baik kinerja yang didapat karyawan tersebut. Tanpa disiplin kerja yang baik, maka sulit bagi organisasi untuk mencapai hasil yang efektif dan efisien.

Menurut Veithazal Rifai (2012: 825), "disiplin kerja adalah suatu alat yang dipergunakan para manajer untuk berkomunikasi dengan karyawan agar mereka bersedia untuk merubah suatu perilaku serta sebagai suatu upaya untuk meningkatkan kesadaran dan kesediaan seseorang dalam memenuhi segala peraturan perusahaan”. Sedangkan menurut Hasibuan (2013: 193), menyatakan "disiplin kerja adalah kesadaran dan kesediaan seseorang mentaati semua peraturan-peraturan dan norma-norma sosial yang berlaku”.

\section{Produktivitas Kerja}

Tujuan dari setiap kegiatan yang dilakukan oleh setiap organisasi adalah untuk meningkatkan produktivitas kerja anggotanya. Secara umum, produktivitas dapat diartikan sebagai kemampuan meningkatkan hasil kerja karyawan yang ditinjau dari sumber daya yang dimiliki oleh setiap masing-masing individu. Untuk lebih jelasnya maka penulis ingin mendifinisikan produktivitas kerja menurut para ahli.

"Produktivitas kerja adalah keefektifan dari penggunaan tenaga kerja dan peralatan yang intinya mengarah pada tujuan yang sama, bahwa produktivitas kerja adalah rasio dari hasil kinerja dengan waktu yang dibutuhkan untuk menghasilkan produk dari seseorang tenaga kerja” (Edy Sutrisno: 2012, 109).

Menurut Hasibuan dalam Edyun (2012) "produktivitas adalah meningkatnya output (hasil) yang sejalan dengan input (masukan). Jika produktivitas naik ini hanya dimungkinkan oleh adanya peningkatan efisiensi (waktu,bahan,tenaga) dan sistem kerja, teknik produksi dan adanya peningkatan keterampilan dari tenaga kerjanya”. Produktivitas kerja Siagian dalam Agustin (2014) adalah kemampuan menghasilkan barang/jasa dari 
berbagai sumber daya dan kemampuan yang dimiliki oleh setiap pekerja/karyawan.

\section{METODE}

Metode penelitian yang dilakukan yaitu penelitian deskriptif kualitatif dengan cara pengumpulan data menggunakan kuesioner yang diberikan kepada seluruh responden. Metode pengumpulan data yang dilakukan meliputi:

1. Wawancara (Interview)

Menurut Sugiyono (2016: 137), "wawancara digunakan sebagai teknik pengumpulan data apabila peneliti ingin melakukan studi pendahuluan untuk menemukan permasalahan yang harus diteliti, dan juga apabila peneliti ingin mengetahui hal-hal dari responden yang lebih mendalam dan jumlah respondennya sedikit atau kecil”. Dalam teknik ini penulis melakukan wawancara dengan mengadakan tanya jawab langsung kepada pihak yang berhubungan dengan masalah yang sedang diteliti, sehingga mendapatkan informasi dan jawaban yang lebih mendalam lagi secara lisan.

Metode ini digunakan untuk melengkapi data yang perlu, sehingga lebih menyakinkan data yang diperoleh dari sumber-sumber lainnya. Dalam pelaksanaan wawancara ini, penulis mengadakan wawancara kepada HRD dan karyawan pada Koperasi Simpan Pinjam Sejahtera Bersama.
2. Angket (Kuesioner)

Menurut Sugiyono (2016:142), "kuesioner merupakan teknik pengumpulan data yang dilakukan dengan cara memberi seperangkat pernyataan tertulis kepada responden untuk dijawabnya”. Kuesioner merupakan teknik pengumpulan data yang efisien bila peneliti tahu dengan pasti variabel yang akan diukur dan tahu apa yang bisadiharapkan dari responden.

Angket ini terdiri dari dua variabel yaitu variabel $\mathrm{X}_{1}$ dan $\mathrm{X}_{2}$ (sebagai variable bebas atau independen) mengenai budaya organisasi dan disiplin kerja serta variabel Y (sebagai variable terikat atau dependen) mengenai produktivitas kerja. Angket ini ditujukan kepada karyawan yang dijadikan sampel responden untuk mendapatkan data dan informasi yang berhubungan dengan budaya organisasi dan kedisiplinan terhadap produktivitas kerja karyawan pada Koperasi Simpan Pinjam Sejahtera Bersama.

3. Observasi

Menurut Sugiyono (2016:145), “observasi sebagai teknik pengumpulan dan mempunyai ciri yang spesifik bila dibandingkan dengan teknik yang lain, yaitu wawancara dan kuesioner". Dalam penelitian ini penulis melaksanakan pengamatan langsung di lokasi Koperasi Simpan Pinjam Sejahtera Bersama di Bogor dimana pengamatan terbatas pada pokok permasalahan yang sudah 
disinggung pada pokok permasalahan diatas, yakni mengenai budaya organisasi, disiplin dan produktivitas kerja sehingga data yang diperoleh merupakan data nyata (riil) yang relevan dan objektif.

\section{Populasi dan Sampel}

1. Populasi

Yang dimaksud "populasi adalah wilayah generalisasi yang terdiri atas: obyek atau subyek yang mempunyai kualitas dan karakteristik teretentu yang ditetapkan oleh peneliti untuk dipelejari dan kemudian ditarik kesimpulannya" (Sugiyono: 2016, 80). Populasi penelitian pada Koperasi Simpan Pinjam Sejahtera Bersama Bogor sebanyak 150 karyawan.

2. Sampling (Sampel)

"Sampel adalah sebagian dari populasi yang akan diteliti” (Sugiyono: 2016, 81). Sampel dalam penelitian ini diambil menggunakan rumus Slovin:

$$
n=\frac{\mathrm{N}}{1+\mathrm{N}(\mathrm{e})^{2}}
$$

Dimana:

$$
\begin{aligned}
& \mathrm{n}=\quad \text { Jumlah responden } \\
& \mathrm{N}=\quad \text { Jumlah Populasi } \\
& \mathrm{e}=\text { error } \text { (Ketidak telitian karena } \\
& \text { kesalahan pengambilan sampel } \\
& \text { yang dapat ditolerin) }
\end{aligned}
$$

Berdasarkan rumus Slovin diatas dan dengan menggunakan margin error 10\%, maka penggunaan sampel dalam penelitian ini adalah sebagai berikut:

$$
n=\frac{\mathrm{N}}{1+\mathrm{N}(\mathrm{e})^{2}}
$$

$$
\begin{aligned}
& n=\frac{\mathrm{N}}{1+\mathrm{N}(\mathrm{e})^{2}} \\
& \mathrm{n}=60
\end{aligned}
$$

Dari perhitungan diatas maka dapat disimpulkan bahwa sampel yang dipergunakan dalam penelitian ini adalah sebanyak 60 karyawan pada Koperasi Simpan Pinjam Sejahtera Bersama di Bogor menggunakan Teknik random sampling.

\section{HASIL dan PEMBAHASAN}

\section{Uji Validasi}

1. Uji Validasi Budaya Organisai $\left(\mathrm{X}_{1}\right)$

Tabel. 1.3. Uji Validasi Disiplin Kerja $\left(X_{1}\right)$

\begin{tabular}{|c|c|c|c|}
\hline $\begin{array}{c}\text { Perta } \\
\text { nyaan }\end{array}$ & (rhitung) & (rtabel) & Ket. \\
\hline P.1 & 0.456 & 0.245 & Valid \\
\hline P.2 & 0.650 & 0.245 & Valid \\
\hline P.3 & 0.352 & 0.245 & Valid \\
\hline P.4 & 0.300 & 0.245 & Valid \\
\hline P.5 & 0.423 & 0.245 & Valid \\
\hline P.6 & 0.395 & 0.245 & Valid \\
\hline P.7 & 0.527 & 0.245 & Valid \\
\hline P.8 & 0.587 & 0.245 & Valid \\
\hline P.9 & 0.432 & 0.245 & Valid \\
\hline P.10 & 0.595 & 0.245 & Valid \\
\hline P.11 & 0.446 & 0.245 & Valid \\
\hline P.12 & 0.623 & 0.245 & Valid \\
\hline
\end{tabular}

Sumber: Olah Data Primer SPSS.22

Dari tabel, diperoleh bahwa semua butir dinyatakan valid karena nilai $\mathrm{r}_{\text {hitung }}$ semua pernyataan no. 1 sampai dengan 12 nilain $r_{\text {hitung-nya lebih besar dari nilai } r \text { tabel }}$ 0,245 .

2. Uji Validitas Disiplin Kerja $\left(\mathrm{X}_{2}\right)$

Tabel 1.4. Uji Validasi Disiplin Kerja $\left(X_{2}\right)$

\begin{tabular}{|c|c|c|c|}
\hline $\begin{array}{c}\text { Perta } \\
\text { nyaan }\end{array}$ & $\left.\mathbf{( r}_{\text {hitung }}\right)$ & $\left.\mathbf{( r}_{\text {tabel}}\right)$ & Ket. \\
\hline P.1 & 0,449 & 0.245 & Valid \\
\hline P.2 & 0,616 & 0.245 & Valid \\
\hline
\end{tabular}




\begin{tabular}{|c|c|c|c|}
\hline $\begin{array}{c}\text { Perta } \\
\text { nyaan }\end{array}$ & (rhitung) & (rtabel) & Ket. \\
\hline P.3 & 0,410 & 0.245 & Valid \\
\hline P.4 & 0,346 & 0.245 & Valid \\
\hline P.5 & 0,415 & 0.245 & Valid \\
\hline P.6 & 0,464 & 0.245 & Valid \\
\hline P.7 & 0,510 & 0.245 & Valid \\
\hline P.8 & 0,560 & 0.245 & Valid \\
\hline P.9 & 0,404 & 0.245 & Valid \\
\hline P.10 & 0,545 & 0.245 & Valid \\
\hline P.11 & 0,419 & 0.245 & Valid \\
\hline P.12 & 0,587 & 0.245 & Valid \\
\hline P.13 & 0,449 & 0.245 & Valid \\
\hline P.14 & 0,616 & 0.245 & Valid \\
\hline P.15 & 0,410 & 0.245 & Valid \\
\hline P.16 & 0,346 & 0.245 & Valid \\
\hline P.17 & 0,415 & 0.245 & Valid \\
\hline P.18 & 0,464 & 0.245 & Valid \\
\hline
\end{tabular}

Sumber: Olah Data Primer SPSS.22

Dari tabel, semua butir dinyatakan valid karena nilai $r_{\text {hitung }}$ semua pernyataan no. 1 sampai dengan 18 nilainya lebih besar dari nilai $r_{\text {tabel }} 0,245$.

\section{Uji Validitas Produktiitas (Y)}

Tabel. 1.5. Uji Validasi Produktivitas (Y)

\begin{tabular}{|c|c|c|c|}
\hline $\begin{array}{l}\text { Perta } \\
\text { nyaan }\end{array}$ & (rhitung) & $\left(\mathbf{r}_{\text {tabel }}\right)$ & Ket. \\
\hline P.1 & 0,584 & 0.245 & Valid \\
\hline P.2 & 0,535 & 0.245 & Valid \\
\hline P.3 & 0,364 & 0.245 & Valid \\
\hline P.4 & 0,611 & 0.245 & Valid \\
\hline P.5 & 0,611 & 0.245 & Valid \\
\hline P.6 & 0,611 & 0.245 & Valid \\
\hline P.7 & 0,304 & 0.245 & Valid \\
\hline P.8 & 0,357 & 0.245 & Valid \\
\hline P.9 & 0,524 & 0.245 & Valid \\
\hline P.10 & 0,503 & 0.245 & Valid \\
\hline P.11 & 0,477 & 0.245 & Valid \\
\hline P.12 & 0,568 & 0.245 & Valid \\
\hline P.13 & 0,763 & 0.245 & Valid \\
\hline P.14 & 0,265 & 0.245 & Valid \\
\hline
\end{tabular}

Dari tabel, semua butir dinyatakan valid karena nilai $\mathrm{r}_{\text {hitung }}$ semua pernyataan no. 1 sampai dengan 14 nilainya lebih besar dari nilai $r_{\text {tabel }} \mathbf{0 , 2 4 5}$.

\section{Uji Reliabilitas}

"Uji reliabilitas dikatakan reliable atau handal jika jawaban responden terhadap pernyataan adalah konsisten atau stabil dari waktu ke waktu” (Sugiono: 2016, 183). "Variabel dikatakan Reliabel jika nilai Cronbach's Alpha > 0,60" (Ernawati, 2013: 82). Berikut hasil uji reliabilitas variabel budaya organisasi, disiplin kerja dan produktivitas kerja karyawan.

Tabel 1.6. Hasil Uji Reliabilitas Budaya Organisasi Reliability Statistics

\begin{tabular}{|r|r|}
\hline Cronbach's Alpha & N of Items \\
\hline 696 & 12 \\
\hline \multicolumn{2}{|c|}{ Sumber: Data Primer yang diolah }
\end{tabular}

Tabel 1.7. Hasil Uji Reliabilitas Disiplin Kerja $\left(X_{2}\right)$

Reliability Statistics

\begin{tabular}{|r|c|}
$\mid$ Cronbach's Alpha & N of Items \\
\hline, 788 & 18 \\
\hline \multicolumn{2}{|c|}{ Sumber: Data Primer yang diolah }
\end{tabular}

Tabel 1.8. Hasil Uji Reliabilitas Produktivitas (Y)

Reliability Statistics

\begin{tabular}{|r|c|}
\hline Cronbach's Alpha & N of Items \\
\hline, 720 & 14 \\
\hline \multicolumn{2}{|c|}{ Sumber: Data Primer yang diolah }
\end{tabular}

Dari pengujian di atas, karena nilai seluruh nilai cronbach's alpha variabel budaya organisasi, disiplin kerja dan produktivitas kerja lebih besar dari o.6o, maka semua variabel dikatakan reliabel. 


\section{Uji Hipotesis}

\section{Regresi Linier Berganda}

Tabel 1.9. Hasil Analisis Regresi Linier Berganda Coefficients ${ }^{\mathrm{a}}$

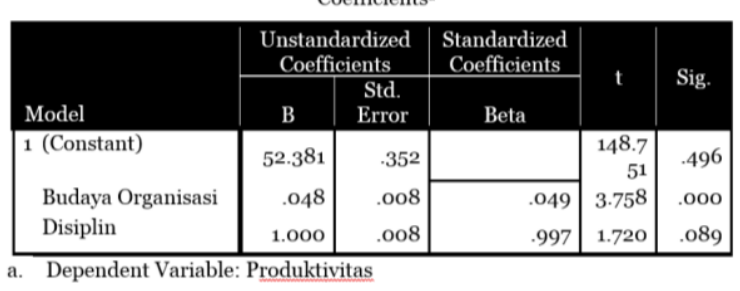

Sumber: Data Primer yang diolah SPSS 22

Dari tabel diperoleh persamaan regresi ganda $\hat{Y}=52,381+0,048 X_{1}+1,000 X_{2}$

1) Nilai konstanta 52,381 , menunjukkan apabila jika Budaya Organisasi dan Disiplin Kerja nilainya konstan maka Produktivitas Karyawan pada Koperasi Simpan Pinjam Sejahtera Bersama Bogor nilainya sebesar 52,381.

2) Koefisien regresi variabel Budaya Organisasi nilai bernilai positif 0,048 , dapat diartikan bahwa setiap peningkatan pada budaya organisasi sebesar satu satuan, maka akan Produktivitas Karyawan pada Koperasi Simpan Pinjam Sejahtera Bersama Bogor akan meningkat sebesar 0,048 satuan dengan asumsi variabel independen lain bernilai tetap.

3) Koefisien regresi variabel disiplin kerja nilai bernilai positif 1,000, dapat diartikan bahwa setiap peningkatan pada disiplin kerja sebesar satu satuan, maka akan Produktivitas Karyawan pada Koperasi Simpan Pinjam Sejahtera Bersama Bogor akan meningkat sebesar 1,000 satuan dengan asumsi variabel independen lain bernilai tetap.

\section{Uji Statistik Fisher (Uji F)}

Uji $\mathrm{F}$ digunakan untuk mengetahui pengaruh simultan (bersama-sama) variabel budaya organisasi dan disiplin kerja terhadap produktivitas karyawan.

\begin{tabular}{|c|c|c|c|c|c|}
\hline \multicolumn{6}{|c|}{$\begin{array}{c}\text { Tabel.1.10. Hasil Uji Statistik Fisher } \\
\text { ANOVA }^{a}\end{array}$} \\
\hline Model & $\begin{array}{c}\text { Sum of } \\
\text { Squares }\end{array}$ & $D f$ & $\begin{array}{l}\text { Mean } \\
\text { Square }\end{array}$ & $F$ & Sig. \\
\hline 1 Regression & 1176.709 & 2 & 588.354 & 8098.471 & $.000^{b}$ \\
\hline Residual & 4.141 & 57 & 0.073 & & \\
\hline Total & 1180.850 & 59 & & & \\
\hline
\end{tabular}

Sumber: Data Primer yang diolah

Hasil uji $F$ diperoleh nilai $F_{\text {hitung }}$ (8098.471) > $\mathrm{F}_{\text {tabel }}(3,160)$ dan nilai probabilitas 0,000. Artinya secara simultan budaya organisasi dan disiplin kerja berpengaruh terhadap Produktivitas Karyawan pada Koperasi Simpan Pinjam Sejahtera Bersama Bogor.

\section{Koefisien Determinasi}

Tabel 1.11. Hasil Uji Koefisien Korelasi $\mathbf{R}^{2}$ Model Summary ${ }^{\mathrm{b}}$

\begin{tabular}{|l|c|r|r|r|} 
Model & \multicolumn{1}{|c|}{$\mathrm{R}$} & $\begin{array}{c}\mathrm{R} \\
\text { Square }\end{array}$ & $\begin{array}{c}\text { Adjusted R } \\
\text { Square }\end{array}$ & $\begin{array}{l}\text { Std. Error of } \\
\text { the Estimate }\end{array}$ \\
\hline & \multicolumn{1}{|c|}{$.998^{\mathrm{a}}$} & .996 & .996 & .270 \\
\hline
\end{tabular}

a. Predictors: (Constant), Budaya organisai dan Disiplin b. Dependent Variable: Produktivitas Sumber: Data Primer yang diolah

Hasil uji koefisien determinasi diperoleh konstribusi budaya organisasi dan disiplin kerja terhadap produktivitas karyawan sebesar 0,996. Artinya 99,6\% Produktivitas karyawan Koperasi Simpan Pinjam Sejahtera Bersama Bogor dipengaruhi oleh budaya organisasi dan disiplin kerja, sedangkan sisanya sebesar 0,04\% dipengaruhi oleh faktor-faktor lain yang tidak diteliti. 


\section{Uji t}

Uji $\mathrm{t}$ digunakan untuk mengetahui pengaruh parsial apakah variabel independen terhadap variabel dependen.

\begin{tabular}{l|r|r|r|r|r|}
\hline \multicolumn{7}{|c|}{ Tabel 1.12. Uji Statisitik t } \\
Coefficients $^{\mathrm{a}}$
\end{tabular}

Dari tabel di atas diperoleh hasil uji $\mathrm{t}$ sebagai berikut:

a) Pengaruh Budaya Organisasi terhadap Produktivitas Karyawan pada Koperasi Simpan Pinjam Sejahtera Bersama Bogor (Y)

Hasil uji t diperoleh nilai $t_{\text {hitung }}=6,188=$ lebih besar dari $t_{\text {tabel }}=2,001$ dengan nilai signifikan o,ooo. Artinya budaya organisasi berpengaruh signifikan terhadap produktivitas karyawan pada Koperasi Simpan Pinjam Sejahtera Bersama Bogor.

b) Pengaruh Disiplin kerja $\left(\mathrm{X}_{2}\right)$ terhadap Produktivitas Karyawan (Y)

Hasil uji $\mathrm{t}$ diperoleh nilai $\mathrm{t}_{\text {hitung }}=127,117$ lebih besar dari $t_{\text {tabel }}=2,001$ dengan nilai signifikan o,ooo. Artinya disiplin kerja berpengaruh signifikan terhadap produktivitas karyawan pada Koperasi Simpan Pinjam Sejahtera Bersama Bogor.

\section{SIMPULAN}

\section{Kesimpulan}

1. Secara parsial budaya organisasi berpengaruh terhadap produktivitas kerja dengan $t_{\text {hitung }}=6,188$ lebih besar dari $t_{\text {tabel }}=2,001$, dengan nilai signifikansi o,ooo.

2. Secara parsial disiplin kerja berpengaruh terhadap produktivitas kerja dengan $t_{\text {hitung }}=127,117$ lebih besar dari $t_{\text {tabel }}=2,001$ dengan nilai signifikan 0,000.

3. Secara simultan terdapat pengaruh yang signifikan antara budaya organisasi dan disiplin kerja terhadap produktivitas karyawan pada Koperasi Simpan Pinjam dengan hasil uji F nilai $F_{\text {hitung }}$ (8098.471) $>\mathrm{F}_{\text {tabel }}$ (2.001). Hal ini menyatakan semakin baik pengaruh budaya organisasi dan disiplin kerja terhadap produktivitas karyawan yang diberikan oleh Koperasi Simpan Pinjam Sejahtera Bersama Bogor.

\section{Saran}

Saran-saran yang bisa disampaikan dalam penelitian ini antara lain

1. Budaya organisasi dengan memberikan standar operasi pekerjaan yang sistematis agar dapat diserap dengan baik oleh karyawan sehingga pekerjaan dapat tercapai secara efektif dan efisien.

2. Disiplin kerja yang dilaksanakan seluruh karyawan Koperasi Simpan Pinjam Sejahtera Bersama Bogor sudah baik, namun yang perlu diperhatikan dan ditingkatkan lagi beberapa aspek 
diantaranya kehadiran dan absensi karyawan yang dapat meningkatkan produktivitas kerja.

3. Produktivitas kerja yang dilaksanakan pada Koperasi Simpan Pinjam Sejahtera Bersama Bogor sudah baik, namun perlu diperhatikan lagi budaya kerja yang baik agar karyawan terus termotivasi untuk maju.

\section{DAFTAR PUSTAKA}

A.F. Stoner. 2011. “Manajemen Sumber

Daya Manusia”. Jakarta: Bumi Aksara.

A.A. Anwar Prabu Mangkunegara. 2012. "Manajemen Sumber Daya Manusia”. Cetakan Ke Tujuh. Bandung : PT. Remaja Rosdakarya.

Hasibuan. Malayu SP.2012. "Manajemen Sumber Daya Manusia”. Jakarta: Bumi Aksara

Prenadamedia Group. Ghozali Imam. 2006. "Aplikasi Analisis Multivarite dengan SPSS”. Semarang : Badan Penerbit Universitas Diponegoro.

Rifai Vithazal. 2012. "Manajemen Sumber Daya Manusia Untuk Perusahaan". Jakarta: Rajawali Pers.

Robbins SP, dan Judge. 2012. "Perilaku Organisasi”. Jakarta: Salemba Empat Hal 22.

Sedarmayanti. 2012. "Manajemen Sumber Daya Manusia, Reformasi Birokrasi dan Manajemen Pegawai Negeri
Sipil”. Bandung : PT Refika Adiatama.

Sugiyono. 2016. "Metode Penelitian Pendidikan: Pendekatan Kuantitatif. Kualitatif. dan $R \& D ”$. Bandung: Alfabeta.

Sutrisno Edy. 2014. "Manajemen Sumber Daya Manusia”. Cet. 6. Jakarta: Prenada Media Group

T. Hani Handoko. 2014. "Manajemen Personalia dan Sumber Daya Manusia”. BPFE Yogyakarta. . 2014. "Manajemen Edisi 2”. Yogyakarta : BPFE Yogyakarta. 